\title{
Effects of low-level laser therapy after nerve reconstruction in rat denervated soleus muscle adaptation
}

\author{
Efeitos do laser de baixa potência após reconstrução nervosa na adaptação do \\ músculo sóleo de rato
}

Marcela A. Silva-Couto, Davilene Gigo-Benato, Carla R. Tim, Nivaldo A. Parizotto, Tania F. Salvini, Thiago L. Russo

\begin{abstract}
Background: Peripheral nerve injury (PNI) rehabilitation remains a challenge for physical therapists because PNI effects are very disabling. Low-level laser therapy (LLLT) has been described as a physical resource that is able to influence enzymes called metallopeptidases (MMPs) associated with extracellular matrix (ECM) turnover, thus accelerating neuromuscular recovery after nerve crush injuries. However, the effects of LLLT in the treatment of severe nerve injuries and denervated slow-twitch muscles are still inconclusive. Objectives: The aim of this study was to evaluate the effects of different wavelengths and energy densities of LLLT irradiation, applied to a severe nerve injury after reconstruction, on denervated slow-twitch skeletal muscle adaptation. Method: Rats were submitted to a neurotmesis of the sciatic nerve followed by end-to-end neurorrhaphy. They received transcutaneous LLLT irradiation at the lesion site. The LLLT parameters were: wavelengths - 660 or $780 \mathrm{~nm}$; energy densities - 10, 60 or $120 \mathrm{~J} / \mathrm{cm}^{2}$; power - $40 \mathrm{~mW}$; spot - 4 mm². Sciatic functional index (SFI), histological, morphometric, and zymographic analyses were performed. One-way ANOVA followed by Tukey's test was used ( $p \leq 0.05)$. Results: An atrophic pattern of muscle fibers was observed in all injured groups. The MMP activity in the soleus muscle reached normal levels. On the other hand, SFI remained below normality after PNI, indicating incapacity. No difference was found among PNI groups submitted or not to LLLT in any variable. Conclusions: LLLT applied to the nerve post-reconstruction was ineffective in delaying degenerative changes to the slow-twitch denervated muscles and in functional recovery in rats. New studies on recovery of denervated slow-twitch muscle are necessary to support clinical practice.
\end{abstract}

Keywords: neurological rehabilitation; nerve injury; laser therapy; skeletal muscle; physical therapy.

\section{Resumo}

Contextualização: A reabilitaçao das lesões nervosas periféricas (LNP) ainda é um desafio para a fisioterapia. A terapia com o laser de baixa potência (LBP) é descrita como um recurso físico capaz de interagir com enzimas relacionadas à alteração da matrix extracelular. Denominadas metalopeptidases (MMPs), essas enzimas atuam durante a recuperação neuromuscular após LNP. No entanto, os efeitos da LBP no tratamento de músculos desnervados de contração lenta após LNP graves ainda são inconclusivos. Objetivo: Avaliar os efeitos de diferentes comprimentos de onda e densidades de energia de irradiação de LBP, aplicado sobre o local do nervo após LNP grave e reconstrução. Método: Ratos foram submetidos a neurotmese do nervo isquiático e neurorrafia término-terminal. Os parâmetros do laser são: comprimento de onda: 660 ou 780 nm; densidades de energia: 10, 60 ou $120 \mathrm{~J} / \mathrm{cm}^{2}$; potência: 40 mw; spot: 4 mm². O índice funcional isquiático (IFC) e análises histológicas, morfométricas e zimografia foram realizados. ANOVA one-way e teste de Tukey $(p \leq 0,05)$ foram utilizados. Resultados: Um padrão atrófico das fibras musculares foi observado em todos os grupos com LNP. A atividade das MMPs no músculo sóleo alcançaram níveis normais. Entretanto, o IFC permaneceu inferior à normalidade após a LNP, indicando incapacidade. Não houve diferença entre os grupos de LNP submetidos ou não à LBP em qualquer variável. Conclusão: O LBP é incapaz de retardar alterações degenerativas em músculos sóleos desnervados e é ineficaz na recuperação funcional de ratos. Novos estudos sobre a recuperação do músculo de contração lenta desnervados são necessários para apoiar a prática clínica.

Palavras-chave: reabilitação neurológica; desnervação; laserterapia; músculo esquelético; fisioterapia.

Received: 01/30/2012 - Revised: 03/02/2012 - Accepted: 03/20/2012

Physical Therapy Department, Universidade Federal de São Carlos (UFSCar), São Carlos, SP, Brazil

Correspondence to: Thiago Luiz de Russo, Universidade Federal de São Carlos - UFSCar, Departamento de Fisioterapia,Rodovia Washington Luís, km 235, CEP 13565-905, São Carlos, SP, Brasil, e-mail: thiago_russo@yahoo.com.br 


\section{Introduction $: \because$.}

Peripheral nerve injury (PNI) rehabilitation remains a challenge for physical therapists. This type of injury causes paralysis and causes profound degenerative alterations to skeletal muscle, leading to atrophy ${ }^{1}$ and force deficits ${ }^{2}$, thus impairing funcionality ${ }^{3}$. According to a Brazilian study, out of 456 cases analyzed, $41 \%$ of PNIs are neurotmesis 4 . In this type of PNI, there is nerve discontinuity as well as perineural disruption and in many cases loss of nerve tissue $\mathrm{e}^{5}$. The patient is impaired both economically and socially in the occurrence of PNI, therefore post-operative treatment should aim for maximal restoration of patient functionality by stimulating neuronal growth and maintaining muscle trophism until reinnervation occurs.

The denervated skeletal muscle is a rich scenario of modifications that still has not been fully clarified. PNIs usually generate not only muscle fiber atrophy, but also incite alterations to the extracellular matrix (ECM) surrounding these fibers ${ }^{6}$. For example, denervated muscles have extensive endomysium and perimysium proliferation ${ }^{4}$. Often such proliferation can be associated with flexibility reduction, fibrosis, and deficits in the conduction of tension forces ${ }^{7}$. In this sense, ECM reorganisation is an important element to understanding the mechanisms of muscle adaptation in denervation.

MMPs are a zinc-dependent proteolytic enzyme family involved in the ECM remodeling process. They can be synthesized and secreted in the skeletal muscle by Schwann cells, satellite cells, and fibroblasts, specifically in the intramuscular nerves and the neuromuscular junction (NMJ) $)^{8,9}$. Among these enzymes, the MMP-2 (gelatinase A) and the MMP-9 (gelatinase B) are key to the ECM remodeling process in the skeletal muscle during changes in the intensity of physical activity or in cases of changes to task demands and to the process of injury repair8.

These enzymes are known for acting on a non-fibrillar form of type IV collagen degradation and interstitial collagen hydrolysis ${ }^{10}$. The investigation concerning MMP activity is clinically relevant because MMPs act directly on collagen turnover and, therefore, on fibrosis formation, flexibility reduction, and mechanical force alterations in denervated muscles ${ }^{7}$. Furthermore, previous studies reported that MMPs can be involved in the reinnervation process of denervated muscle fibers ${ }^{6,10}$ and probably allow axonal growth cones to advance into the muscle ECM.

In this context, the regulation of MMPs in denervated muscles has great importance to clinical practice. Understanding how the resources normally used by the rehabilitation team can affect MMP activation can provide a scientific basis for its use in humans. Among the possible candidates that promote neuromuscular recovery in PNI is low-level laser therapy (LLLT).
Recently, it was demonstrated that LLLT accelerates muscle fiber cross-section area (CSA) recovery in denervated fast-twitch muscles of rats when LLLT is applied to crushed nerves ${ }^{3}$. These authors concluded that LLLT irradiation accelerated neuromuscular recovery by increasing MMP-2 activation in the injured nerve and inhibiting the activation of MMP-9 and -2 in injured nerves and denervated muscles, respectively. These changes in MMP activation were also associated with walking recovery ${ }^{3}$. This study has brought subsidies for future indications of LLLT use in humans. However, studies are needed on slow-twitch muscle adaptation during severe nerve injuries.

The objective of this study was to evaluate the response of a denervated slow-twitch skeletal muscle (soleus) to LLLT irradiation applied to an injured nerve. A severe nerve injury model (neurotmesis), followed by end-to-end neurorrhaphy reconstruction, was used in the present study in an attempt to mimic clinical situations. Furthermore, special attention was given to the selection of irradiation parameters, muscle function and trophism, and ECM adaptation in denervated muscles. This work is relevant to neurological rehabilitation because it considers a common situation in physical therapy practice. Moreover, the use of the animal model in this study is justified due to ethical reasons surrounding the biopsy of denervated muscles in humans. Finally, the hypothesis of this study was that LLLT irradiation in injured-reconstructed nerves is able to accelerate nerve recovery and muscle reinnervation, improving function and reestablishing soleus muscle trophism via the regulation of MMP activity.

\section{Method : :}

Animal care and experimental groups - Sixty-four male 3-month-old Wistar rats $(275 \mathrm{~g})$ were used. The animals were housed in plastic cages in a room with controlled environmental conditions and free access to water and standard food. The Ethics Committee of Universidade Federal de São Carlos (UFSCar), São Carlos, SP, Brazil, approved the experimental procedures (Process 001/06), and the study was conducted in accordance with the national guide for care and use of laboratory animals.

\section{Experimental groups}

The animals were randomly divided into eight groups $(\mathrm{n}=8)$ : (1) normal (N) in which the animals received no intervention and remained free in the cage for 84 days; (2) transected nerve and end-to-end neurorrhaphy (TT) with simulation treatment (placebo) for one minute; (3) transected nerve and end-to-end 
neurorrhaphy irradiated with LLLT $660 \mathrm{~nm} 10 \mathrm{~J} / \mathrm{cm}^{2}$ (TT660 10); (4) transected nerve and end-to-end neurorrhaphy irradiated with LLLT $660 \mathrm{~nm} 60 \mathrm{~J} / \mathrm{cm}^{2}$ (TT660 60); (5) transected nerve and end-to-end neurorrhaphy irradiated with LLLT $660 \mathrm{~nm} 120 \mathrm{~J} / \mathrm{cm}^{2}$ (TT660 120); (6) transected nerve and end-to-end neurorrhaphy irradiated with LLLT $780 \mathrm{~nm} 10 \mathrm{~J} / \mathrm{cm}^{2}$ (TT780 10); (7) transected nerve and end-to-end neurorrhaphy irradiated with LLLT $780 \mathrm{~nm}$ $60 \mathrm{~J} / \mathrm{cm}^{2}$ (TT780 60); (8) transected nerve and end-to-end neuror-

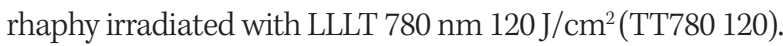

\section{Surgery procedure}

The animals were anesthetised with an intraperitoneal injection of a premixed solution containing ketamine $(95 \mathrm{mg} / \mathrm{kg}$ ) and xylazine $(12 \mathrm{mg} / \mathrm{kg})$. The skin was shaved and cleaned with $10 \%$ povidone iodine. A 2 -cm-long incision was made on the skin through a gluteal approach and the left sciatic nerve was exposed. The sciatic nerve was cut and sutured with a nylon monofilament 8.0 in the epineural region only. This microsurgical procedure was performed by visualization of a surgical magnifying lens with $4 \mathrm{x}$ magnification. The nerves were kept moist with $37^{\circ} \mathrm{C}$ sterile saline solution throughout the surgical intervention. After surgery ${ }^{11,12}$, the animals were housed in single cages and fed rat chow and water ad libitum. For the first four days, acetaminophen $(13.5 \mathrm{mg} / 100 \mathrm{~mL})$ was added to the water for pain reduction. A single dose of the antibiotic Terramycin $(1 \mathrm{mg} / 0.1 \mathrm{~mL})$ was administered to prevent secondary complications related to possible infections.

\section{LLLT protocol and experimental design}

Biostimulation was carried out using a gallium-aluminum-arsenide laser device (TWIN LASER, MM Optics, São Carlos, SP, Brazil) with the following parameters: continuous radiation, wavelength: 660 or $780 \mathrm{~nm}$, power: $40 \mathrm{~mW}$, spot area: $4 \mathrm{~mm}^{2}$, energy density at the point of entry: $10,60 \mathrm{or} 120 \mathrm{~J} / \mathrm{cm}^{2}$. The time of stimulation was predetermined by the device following the abovementioned parameters. All parameters were obtained from Gigo-Benato et al. ${ }^{3}$ and are described in detail in Table 1. Calibration was performed by MM Optics (São Carlos, SP, Brazil). Briefly, a calibrated powermeter was used to verify the power of the laser device. This verification was approved only if the deviation was not higher than $20 \%$ of mean value.

Radiation was applied transcutaneously after shaving the skin over the site of the surgery (recognizable for the presence of the surgical scar) at two points along the sciatic nerve, one above and one below the scar site, and two centimetres apart. Applications were made daily for 10 consecutive days beginning on the first day after surgery and on alternative days for another month. The animals were handled with care. Laser biostimulation did not cause any pain or distress to the animals, therefore it was not necessary to use anesthesia.

\section{Assessment of nerve function recovery}

The assessment of nerve function recovery was carried out by calculating the sciatic functional index (SFI) as described by Bain, Mackinnon and Hunter ${ }^{13}$. Animals were tested in a confined walkway $42 \mathrm{~cm}$ long and $8.2 \mathrm{~cm}$ wide, with a dark shelter at the end. A white sheet of paper was placed on the floor of the rat walkway. The rats' hind paws were pressed down onto a finger paint-soaked sponge, and they were then allowed to walk down the walkway leaving their hind footprints on the paper. Three measurements were taken from the footprints: (1) the print length (PL), i.e. the distance from the heel to the third toe; (2) the toe spread (TS), i.e. distance from the first to the fifth toe; and (3) the intermediate toe spread (ITS), i.e. distance from the second to the fourth toe. All three measurements were taken from the experimental $(\mathrm{E})$ and normal $(\mathrm{N})$ sides. The SFI was calculated according to the following equation ${ }^{14}$ :

$$
\begin{gathered}
\mathrm{SFI}= \\
-38.3[(\mathrm{EPL}-\mathrm{NPL}) / \mathrm{NPL}]+109.5[(\mathrm{ETS}-\mathrm{NTS}) / \\
\\
\mathrm{NTS}]+13.3[(\mathrm{EITS}-\mathrm{NITS}) / \mathrm{NITS}]-8.8
\end{gathered}
$$

\section{Muscle evaluation}

The right soleus muscles were carefully dissected to avoid mechanical injuries. The muscles were then divided in half at the middle of the belly. The proximal fragment was used for the histological and morphometric measurements. The distal fragment was immediately frozen in liquid nitrogen and stored at $-80^{\circ} \mathrm{C}$ (Forma Scientific, Marietta, $\mathrm{OH}$ ) for the zymographic analysis.

Afterwards, the proximal fragment was frozen in isopentane, previously frozen in liquid nitrogen. Muscle samples were placed in plastic tubes and stored at $-80^{\circ} \mathrm{C}$. Histological serial cross-sections $(10 \mu \mathrm{m})$, cut transversely to the muscle main axis, were obtained with a HM 505E cryostat (Microm, Walldorf, Germany) at a level corresponding to the middle belly of the muscle. Muscle sections were stained with $1 \%$ toluidine blue/1\% borax. Pictures from five different regions were obtained using a light microscope (Axiolab, Carl Zeiss, Jena, Germany) equipped with a digital camera (AxioCam HRc, Carl Zeiss, Germany). From each picture, the CSA of 70 randomly chosen fibers was measured using the software Axiovision 3.0.6 SP4 (Carl Zeiss, Jena, Germany). 
Table 1. Parameters of LLLT application in different experimental groups.

\begin{tabular}{|c|c|c|c|c|c|}
\hline $\begin{array}{l}\text { Experimental Groups } \\
n=8\end{array}$ & $\begin{array}{l}\text { Wavelength } \\
(\mathrm{nm})\end{array}$ & $\begin{array}{l}\text { Power } \\
(\mathrm{mW})\end{array}$ & $\begin{array}{c}\text { Energy density } \\
\left(\mathrm{J} / \mathrm{cm}^{2}\right)\end{array}$ & $\begin{array}{c}\text { Total energy emitted } \\
\text { per point }(\mathrm{J})^{*}\end{array}$ & $\begin{array}{c}\text { Time ON } \\
\text { (s) }\end{array}$ \\
\hline $\bar{N}$ & - & - & - & - & - \\
\hline TT & Simulated & Simulated & Simulated & Simulated & 60 \\
\hline TT660 10 & 660 & 40 & 10 & 1.2 & 30 \\
\hline TT660 60 & 660 & 40 & 60 & 2.4 & 60 \\
\hline TT660 120 & 660 & 40 & 120 & 4.8 & 120 \\
\hline TT780 10 & 780 & 40 & 10 & 1.2 & 30 \\
\hline TT780 60 & 780 & 40 & 60 & 2.4 & 60 \\
\hline TT780 120 & 780 & 40 & 120 & 4.8 & 120 \\
\hline
\end{tabular}

*Total energy for point $(\mathrm{J})=$ Power $(\mathrm{W}) \times$ Time on (s).

\section{Zymography}

Tissue extraction and zymographic analysis was performed according to current methodology ${ }^{15,16}$. The molecular mass of gelatinolytic activities was determined by comparison to reference protein molecular mass marker PageRuler Prestained Protein Ladder (Fermentas Life Sciences, Burlington, ON, Canada). Activity bands were identified following a previous description ${ }^{17}$, according to their molecular weights (pro-MMP-2: $72 \mathrm{kDa}$; intermediate-MMP-2: $64 \mathrm{kDa}$; and active-MMP-2: $57 \mathrm{kDa}$ and pro- MMP-9: 92 kDa; intermediate-MMP-9: kDa; active-MMP-9: $81 \mathrm{kDa}$ ). Densitometric quantitative analysis of the protein bands in the zymography was performed using the software GeneTools v3.06 (Syngene, Cambridge, UK).

\section{Statistical analysis}

The Shapiro-Wilk test and Levene's test were applied to evaluate the normality and homogeneity of the results, respectively. Repeated measures ANOVA was performed for the SFI. For the muscle-fiber cross-sectional area and the MMP activity variables, one-way ANOVA was used to identify possible differences among groups. When differences were observed, Tukey's test was performed. For all tests, the significance level was set at 5\% ( $p \leq 0.05)$.

\section{Results $: \because$.}

\section{Sciatic functional index (SFI)}

The pre-neurotmesis (pre-TT) SFI values were considered normal (-7.44). No difference was found among the experimental groups in the pre-TT moment ( $p>0.05$; Figure 1). As expected, on the first day after injury there was a reduction in the SFI compared with pre-TT in all injured groups ( $p>0.05$; Figure 1$)$. On the last day ( $84^{\text {th }}$ day), a partial functional recovery was observed in all injured groups when compared to day 1 ( $\mathrm{p}<0.05$; Figure 1$)$.
Nevertheless, these values remained inferior to those values observed in the normal group ( $\mathrm{p}<0.05$; Figure 1$)$, with no difference among injured groups on day 84 post-injury ( $p>0.05$; Figure 1). No difference was detected among the groups at any point between the first and the last day (data not shown).

\section{Muscle morphology and cross-sectional area (CSA)}

The muscle morphology analysis showed an atrophic pattern of muscle fibers for all injured groups (LLLT irradiated or not) when compared to the normal group (Figure 2). Connective tissue proliferation was observed in the denervated soleus muscles (Figure 2B-G), specially surrounding the muscle fibers (endomysium) and fiber bundles (perimysium) compared to Normal group (Figure 2A).

Moreover, angulated and degenerated fibers were observed in all denervated groups (Figure 2B-G). These characteristics are a direct indication of skeletal muscle modifications caused by the absence of innervation. In these groups, central nuclei were also observed, confirming the myopathic phenotype (Figure 2I).

Muscle fiber atrophy was confirmed by muscle fiber CSA measurement. All denervated groups showed smaller muscle fiber CSA than normal ( $<<0.05$; Figure 3; TT: $-69.2 \%$, TT660 10: -61.5\%; TT660 60: -46.1\%; TT660 120: -64.1\%; TT780 10: -51.3\%; TT780 60: $-53.8 \%$ and TT780 120: $-52.6 \%)$. No difference was observed among denervated groups ( $>>0.05$; Figure 3 ).

\section{MMP activity in denervated soleus muscle}

The MMP-9 activity was not detected in any samples of the soleus muscle. In comparison, three MMP-2 isoforms were located (pro, intermediate, and active) in all groups. A representative gel is shown in Figure 4A.

Densitometric analysis showed no difference among denervated and normal groups in any of the isoforms $(p>0.05$; Figure 4B-D). 


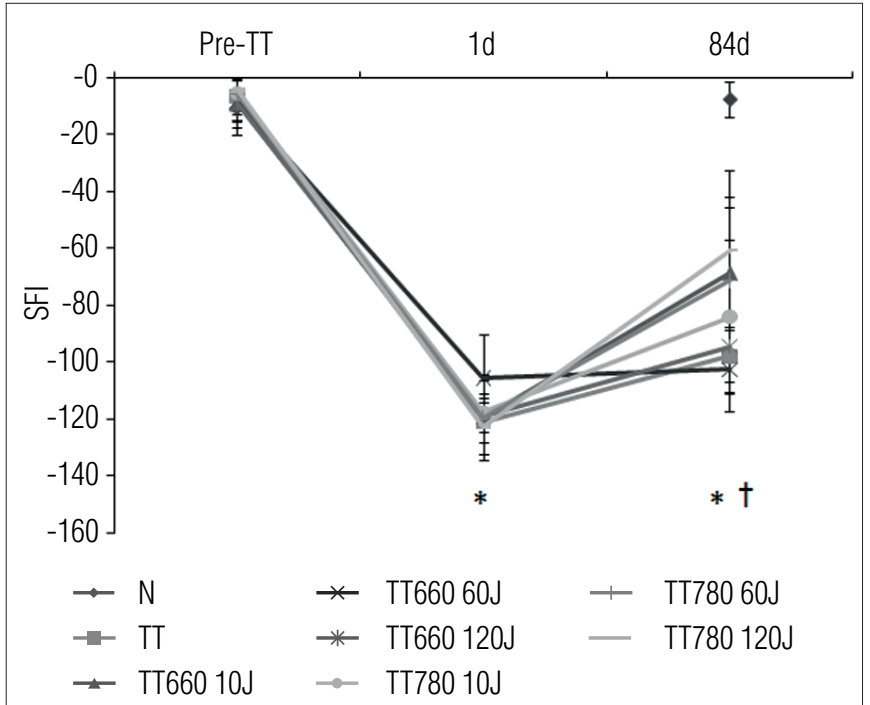

Pre-TT: pre-nerve injury; 1d: first day post-injury; 84d: eighty-fourth day post-injury (last day of the experiment). ${ }^{*} \mathrm{p}<0.05$ for TT, TT660 10, TT660 60, TT660 120, TT780 10, TT780 60, and TT780 120 compared to their own values in $1 \mathrm{~d}$ and N. Note the normal pre-injury (-7.44). On the $1^{\text {st }}$ day post-injury, as expected, there is a significant drop $(-110.40)$ compared to the pre-injury phase. At 84 days post-injury, recovery may be observed in the index, but still well below normal levels $(\uparrow p<0.05)$.

Figure 1. Sciatic functional index (SFI) in different experimental groups.

\section{Discussion $: \because$.}

The present study demonstrated that LLLT applied to reconstructed nerve with the parameters investigated here is unable to avoid degenerative modifications to denervated slow-twitch muscles and ineffective in recovering functionality in rats. The present results did not corroborate the findings observed in denervated fast-twitch muscles whose crushed nerves were irradiated with LLLT ${ }^{3}$.

Recently, Gigo-Benato et al. ${ }^{3}$ pointed out that LLLT irradiation of crushed sciatic nerves caused acceleration in nerve regeneration and contributed toward CSA recovery in the tibialis anterior (TA) muscles of rats. They also demonstrated that a wavelength of $660 \mathrm{~nm}$, with energy densities of 10,60, and $120 \mathrm{~J} / \mathrm{cm}^{2}$, was effective in increasing the MMP-2 activity of the injured nerves, possibly facilitating axonal growth through laminin, fibronectin, and type IV collagen degradation ${ }^{18}$. In addition, LLLT decreased the MMP-9 activity of these nerves, which probably helped to attenuate the inflammatory process. Finally, they demonstrated a decrease in MMP-2 activity in the TA muscles of the crushed groups irradiated with $660 \mathrm{~nm}$ LLLT. The factors that hinder a direct comparison between this and the present study are the differences between the experimental models, namely, the crushing model compared to the nerve section model and the different investigation times.
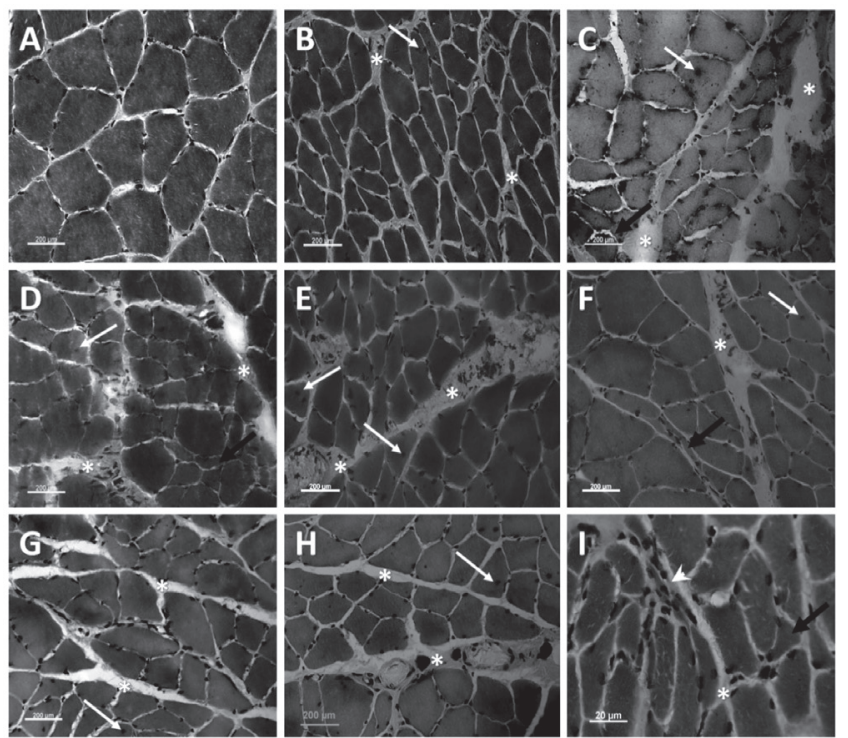

Figure 2. Soleus muscle cross-section of the different experimental groups stained with toluidine blue: A) N; B) TT; C) TT660 10; D) TT660 60; E) TT660 120; F) TT780 10; G) TT780 60; H) TT780 120; and I) TT660 120. White arrows indicate muscle fibers with centralized nuclei; black arrows indicate the angled fibers; asterisks indicate proliferation of connective tissue; and arrow heads indicate the degenerating fibers.

Another factor that may have influenced the findings related to muscle trophism is fiber composition. Gigo-Benato et al. ${ }^{3}$ investigated fast-twitch muscles (TA) composed mainly of type II fibers. However, the present study focused on a slowtwitch muscle (soleus) composed mainly of type I fibers ${ }^{19}$. It has been well described in the literature that slow-twitch muscles exert antigravity function ${ }^{20}$ and respond more to immobilization and disuse situations if compared to fast-twitch muscles. Furthermore, the reduction in oxidative capacity, and the increase in glycolytic metabolism in denervated slow-twitch muscles combined with muscle fiber phenotype transition (from type I to type II) can also interfere with muscular adaptative response $\mathrm{e}^{19,21}$.

Another difference between these studies lies in the fact that: first, slow-twitch muscle fibers are innervated by small motoneurons and fast-twitch muscle fibers are innervated by larger motoneurons ${ }^{22-25}$; and second, that after a nerve injury, Wallerian degeneration occurs from the proximal stump towards the distal followed by neuronal growth cone advance ${ }^{5}$. Thus, a hypothesis generated for the present study is that LLLT could selectively stimulate the neuronal growth cones of large motor units. This hypothesis can be corroborated by two other facts: 1) large motoneuronal growth cones have more mitochondria than those of small motoneurons ${ }^{5}$; and 2) there is evidence that LLLT can act selectively on oxidative metabolism by activating the mitochondrial respiratory chain ${ }^{26}$. LLLT acts 


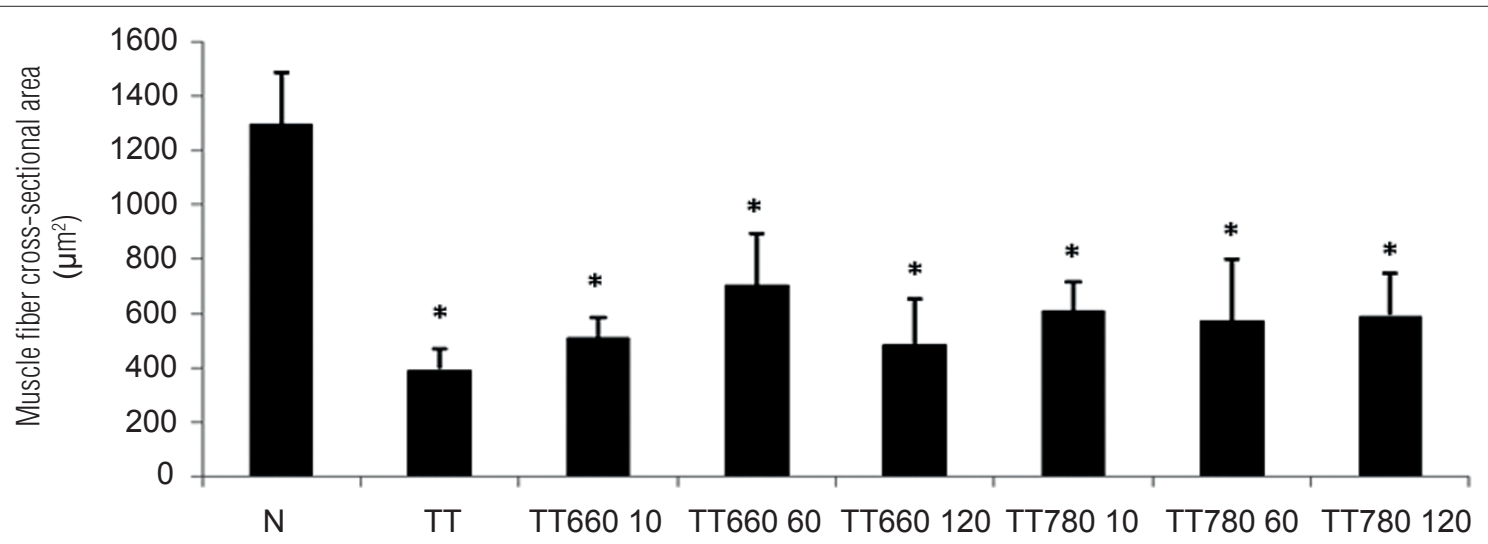

${ }^{*} \mathrm{p}<0.05$ compared to $\mathrm{N}$. Note the decrease in CSA in all groups compared to denervated $\mathrm{N}$. There was no difference between the TT groups irradiated or not with LLLT.

Figure 3. Cross-sectional area (CSA) of soleus muscles from the different experimental groups.

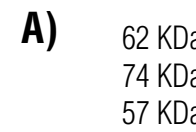

B)

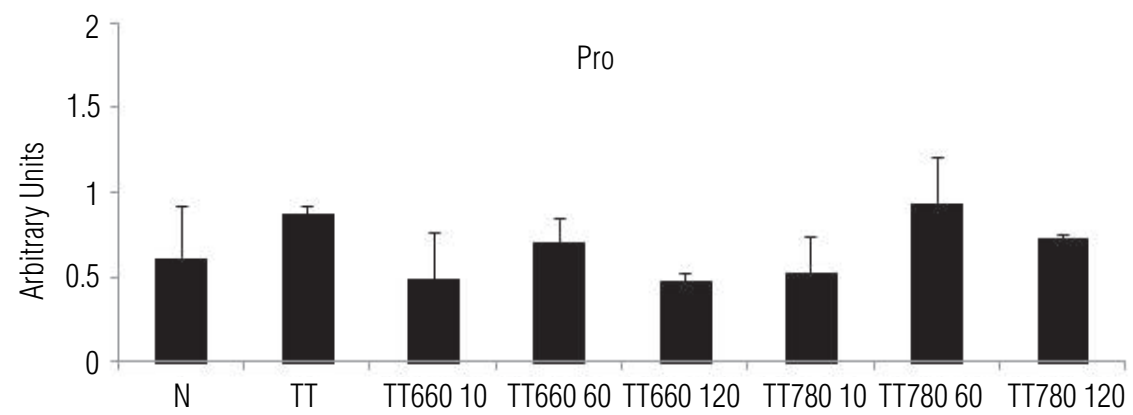

C)

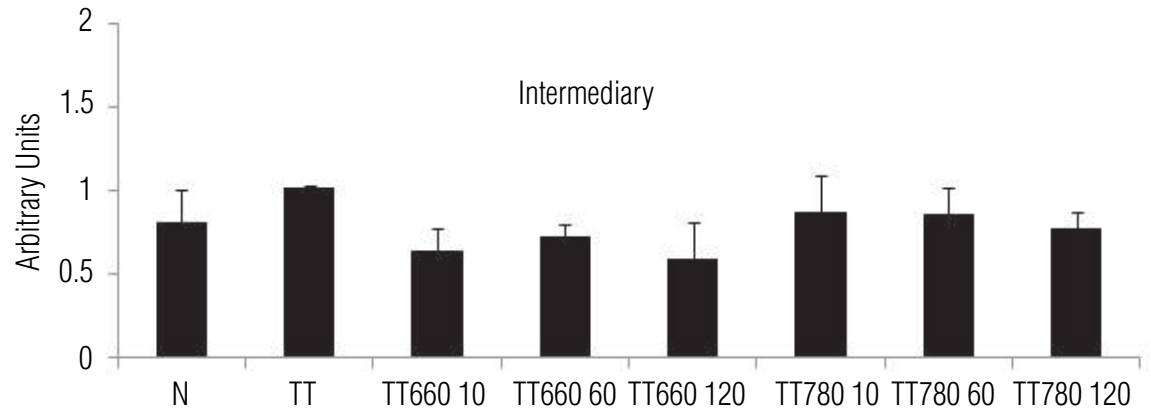

D)

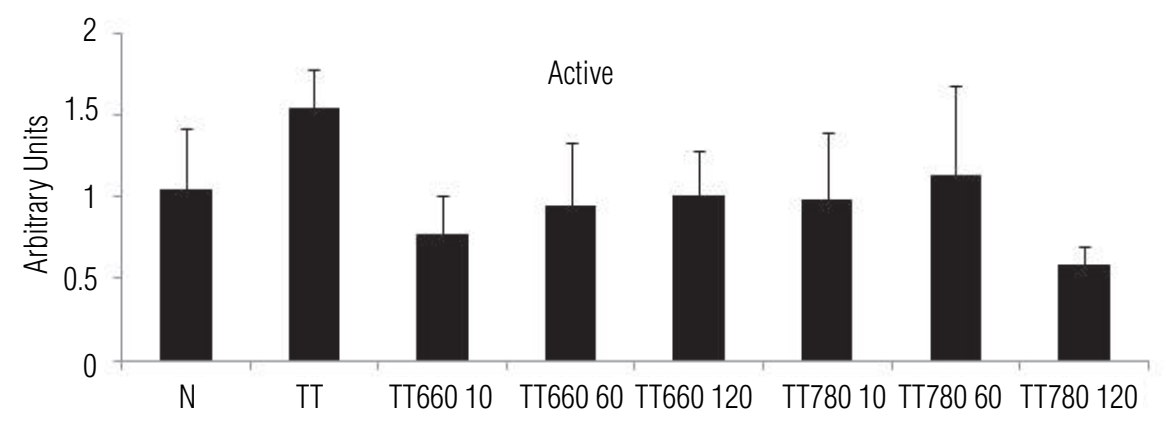

The bands representing MMP-2 gelatinase activity are shown at the top of figure (A). Activity isoforms pro (B), intermediate (C), and active (D). MMP-2 observed in different experimental groups. All experimental groups demonstrated similar values to group $N(p>0.05)$.

Figure 4. MMP-2 activity in denervated soleus muscle. 
on cellular metabolism increasing the size and amount of mitochondria, and oxygen consumption ${ }^{27,28}$. Thus, we believe that LLLT could stimulate the mitochondria of large motor units, facilitating growth cone advance. However, future studies must be performed to test this hypothesis.

Regarding MMP-2 activity, normal levels were found in all denervated soleus muscles. This can be attributed to timing. Demestre et al..$^{6}$ reported an increase in MMP-2 activity in denervated soleus muscles 20 and 40 days after crush nerve injury and a return to normal levels 63 and 72 days after injury, in accordance with the present study. Thus when comparing two types of injury, it is possible to reach the conclusion that MMP activity is normal in later phases of post-neurotmesis recovery.

In contrast, these normal levels of MMP-2 activity could be related to a state of balance that atrophic muscles can reach. Recent studies reported that other degradation pathways, i.e. autophagic pathway, can be involved in late denervated muscle atrophy. In addition, skeletal muscles have strategies to inhibit these pathways and preserve myofibrillar organization, such as the increase in Runx1 (Runt-related transcription factor 1) expression ${ }^{29}$. The present study corroborates this finding because the muscle fiber analysis of the denervated groups showed many signs of injury-regeneration cycles, such as central nucleus and fiber fragmentation. Angled fibers were also observed in all denervated groups, showing a homogeneous pattern in these muscles.

Considering functional recovery, it should be observed that the injury model used in the present study is slower than crush models, with worse prognosis and longer recovery. De Sá et al. ${ }^{30}$ demonstrated that $80 \%$ of nerve function was recovered within 60 days of end-to-end neurorrhaphy. The authors suggested that in a few more weeks the repairing process could be complete. Hence, when evaluating the period of 84 days post-injury, we observed a significant, albeit incomplete, functional improvement in all injured groups (LLLT irradiated or not). New studies should investigate longer times after injury in order to determine the moment of total functional recovery.

It is also worth noting that the present study carried out a dose-response curve following recommendations of clinical protocols of LLLT application. For the wavelength, some studies demonstrated that either visible ${ }^{31-33}$ or near-infrared lasers ${ }^{34}$ are able to stimulate neuronal growth. Energy density is another important parameter to be considered when investigating LLLT effects. Analysis of published results showed that
LLLT at different levels of energy density (ranging from $<10$ to $150 \mathrm{~J} / \mathrm{cm}^{2}$ ) are effective in promoting nerve regeneration. The same is observed for time of irradiation which varies from $<1 \mathrm{~min}$ to $90 \mathrm{~min}$. But despite the evidence that light can affect nerve recovery, the literature is still unclear on the best combination of parameters to improve the regenerative process. Finally, all published studies that reported good results in nerve regeneration used continuous LLLT ${ }^{33,35,36}$. The present study followed all of these recommendations.

The results of the present study have significant clinical considerations. Based on our findings, therapists should keep in mind that denervated slow-twitch muscles do not recover as quickly as fast-twitch muscles ${ }^{3}$. Future studies should focus on interventions not only for the injured nerve, but also for the denervated muscle. Muscle stretching, electrical stimulation, and LLLT have already shown significant results in PNI treatment ${ }^{37-40}$, thus, they should also be considered in future studies for the recovery of denervated slow-twitch muscles.

The present study has some limitations that should be considered. A time-course curve to verify cellular and molecular modifications could provide information about the MMP activity pattern over time and possible correlations with morphological findings. Furthermore, a comparison between fast- and slow-twitch muscles is necessary to investigate the differences in the reinnervation process and MMP content/ activity according to muscle type. Although the present study focused on muscle investigation, other studies should consider the evaluation of morphological and molecular nerve aspects to provide evidence of interaction between LLLT and peripheral nerves.

In conclusion, using a severe PNI standardized model and an LLLT protocol based on literature recommendations, we found that LLLT applied to injured nerves, regardless of the dose, was ineffective in accelerating functional recovery and improving denervated slow-twitch muscle trophism in rats.

\section{Acknowledgements : :}

The Fundação de Amparo à Pesquisa do Estado de São Paulo (FAPESP), São Paulo, SP, Brazil (Process number: 2010/117956) and Conselho Nacional de Desenvolvimento Científico e Tecnológico (CNPq), Brasilia, DF, Brazil, for financial support. 


\section{References $: \because$.}

1. Russo TL, Peviani SM, Durigan JL, Gigo-Benato D, Delfino GB, Salvini TF. Stretching and electrical stimulation reduce the accumulation of MyoD, myostatin and atrogin-1 in denervated rat skeletal muscle. J Muscle Res Cell Motil. 2010;31(1):45-57.

2. Dow DE, Cederna PS, Hassett CA, Kostrominova TY, Faulkner JA, Dennis RG. Number of contractions to maintain mass and force of a denervated rat muscle. Muscle Nerve. 2004;30(1):77-86

3. Gigo-Benato D, Russo TL, Tanaka EH, Assis L, Salvini TF, Parizotto NA. Effects of 660 and $780 \mathrm{~nm}$ low-level laser therapy on neuromuscular recovery after crush injury in rat sciatic nerve. Lasers Surg Med. 2010;42(9):673-82.

4. Kouyoumdjian JA. Peripheral nerve injuries: a retrospective survey of 456 cases. Muscle Nerve. 2006;34(6):785-8

5. Sunderland S. Nerves and nerve injuries. $2^{\mathrm{a}}$ ed. London: Churchill Livingston; 2002.

6. Demestre M, Orth M, Wells GM, Gearing AJ, Hughes RAC, Gregson NA. Characterization of matrix metalloproteinases in denervated muscle. Neuropathol Appl Neurobiol. 2005;31(5): $545-55$

7. Smith AST, Shah R, Hunt NP, Lewis MP. The role of connective tissue and extracellular matrix signaling in controlling muscle development, function, and response to mechanical forces. Semin Orthod. 2010;16(2):135-42

8. Carmeli E, Moas M, Reznick AZ, Coleman R. Matrix metalloproteinases and skeletal muscle: a brief review. Muscle Nerve. 2004;29(2):191-7.

9. Kherif S, Dehaupas M, Lafuma C, Fardeau M, Alameddine HS. Matrix metalloproteinases MMP-2 and MMP-9 in denervated muscle and injured nerve. Neuropathol Appl Neurobiol. 1998;24(4):309-19

10. Ahtikoski AM, Tuominen H, Korpelainen JT, Takala TE, Oikarinen A. Collagen synthesis and degradation in polyneuropathy and myopathies. Muscle Nerve. 2004;30(5):602-8.

11. Dvali L, Mackinnon S. Nerve repair, grafting, and nerve transfers. Clin Plast Surg. 2003;30(2):203-21

12. Shamir MH, Rochkind S, Sandbank J, Alon M. Double-blind randomized study evaluating regeneration of the rat transected sciatic nerve suturing and postoperative low-power laser treatment. J Reconstr Microsurg. 2001;17(2):133-7.

13. Bain JR, Mackinnon SE, Hunter DA. Functional evaluation of complete sciatic, peroneal, and posterior tibial nerve lesions in the rat. Plast Reconstr Surg. 1989;83(1):129-38.

14. Varejão AS, Cabrita AM, Meek MF, Bulas-Cruz J, Melo-Pinto P, Raimondo S, et al. Functional and morphological assessment standardized rat sciatic nerve crush injury with a non-serrated clamp. J Neurotrauma. 2004;21(11):1652-70.

15. Marqueti RC, Parizotto NA, Chriguer RS, Perez SE, Selistre-de-Araújo HS. Androgenic-anabolic steroids associated with mechanical loading inhibit matrix metallopeptidase activity and affect the remodeling of the Achilles tendon in rats. Am J Sports Med. 2006;34(8):1274-80.

16. Peviani SM, Russo TL, Durigan JL, Vieira BS, Pinheiro CM, Galassi MS, et al. Stretching and electrical stimulation regulate the metalloproteinase-2 in rat denervated skeletal muscle. Neurol Res. 2010;32(8):891-6.

17. Carvalho RF, Dariolli R, Justulin Junior LA, Sugizaki MM, Politi Okoshi M, Cicogna AC, et al. Heart failure alters matrix metalloproteinase gene expression and activity in rat skeletal muscle. Int J Exp Pathol. 2006;87(6):437-43.

18. La Fleur M, Underwood JL, Rappolee DA, Werb Z. Basement membrane and repair of injury to peripheral nerve: defining a potential role for macrophages, matrix metalloproteinases, and tissue inhibitor of metalloproteinases-1. J Exp Med. 1996;184(6):2311-26.

19. Lieber RL, Fridén J0, Hargens AR, Feringa ER. Long-term effects of spinal cord transection of fast and slow rat skeletal muscle. II. Morphometric properties. Exp Neurol. 1986;91(3):435-48.

20. Zimowska M, Brzoska E, Swierczynska M, Wstreminska W, Moraczewski J. Distinct patterns of MMP-9 and MMP-2 activity in slow and fast twitch skeletal muscle regeneration in vivo. Int J Dev Biol. 2008;52(2-3):307-14.
21. Zhou, Z, Cornelius CP, Eichner M, Bornemann A. Reinnervation-induced alterations in rat skeletal muscle. Neurobiol Dis. 2006;23(3):595-602.

22. Kandel ER, Schwartz JH, Jessell TM. Principles of neural science. $4^{\text {th }}$ ed. New York: McGraw-Hill; 2000.

23. Lundborg G, Dahlin LB. Anatomy, function, and pathophysiology of peripheral nerves and nerve compression. Hand Clin. 1996;12(2):185-93.

24. Miyauchi A, Kanje M, Danielsen N, Dahlin LB. Role of macrophages in the stimulation and regeneration of sensory nerves by transposed granulation tissue and temporal aspects of the response. Scand J Plast Reconstr Surg Hand Surg. 1997;31(1):17-23

25. Heumann $\mathrm{R}$, Hengerer $\mathrm{B}$, Brown $\mathrm{M}$, Perry $\mathrm{H}$. Molecular mechanisms leading to lesion-induced increases in nerve growth factor synthesis. Ann N Y Acad Sci. 1991;633:581-2.

26. Karu TI. Primary and secondary mechanisms of action of visible-to-near IR radiation on cells. J Photochem Photobiol B. 1999;49(1):1-17.

27. Rizzi CF, Mauriz JL, Freitas Corrêa DS, Moreira AJ, Zettler CG, Filippin LI, et al. Effects of low-leve laser therapy (LLLT) on the nuclear factor (NF)-kappaB signaling pathway in traumatized muscle. Lasers Surg Med. 2006;38(7):704-13.

28. Schroeder P, Pohl C, Calles C, Marks C, Wild S, Krutmann J. Cellular response to infrared radiation involves retrograde mitochondrial signaling. Free Radic Biol Med. 2007;43(1): 128-35.

29. Wang X, Blagden C, Fan J, Nowak SJ, Taniuchi I, Littman DR, et al. Runx1 prevents wasting myofibrillar disorganization, and autophagy of skeletal muscle. Genes Dev. 2005;19(14) 1715-22.

30. De Sá JMR, Mazzer N, Barbieri CH, Barreira AA. The end-to-side peripheral nerve repair Functional and morphometric study using the peroneal nerve of rats. J Neurosci Methods 2004;136(1):45-53

31. Rochkind S, Rousso M, Nissan M, Villarreal M, Barr-Nea L, Rees DG. Systemic effects of lowpower laser irradiation on the peripheral and central nervous system, cutaneous wounds, and burns. Lasers Surg Med. 1989;9(2):174-82.

32. Hamilton GF, Robinson TK, Ray RH. The effects of helium-neon laser upon regeneration of the crushed peroneal nerve. J Orthop Sports Phys Ther. 1992;15(5):209-14.

33. Anders JJ, Geuna S, Rochkind S. Phototherapy promotes regeneration and functional recovery of injured peripheral nerve. Neurol Res. 2004;26(2):233-9.

34. Rochkind S, El-Ani D, Nevo Z, Shahar A. Increase of neuronal sprouting and migration using $780 \mathrm{~nm}$ laser phototherapy as procedure for cell therapy. Lasers Surg Med. 2009;41(4) 277-81.

35. Gigo-Benato D, Geuna S, de Castro Rodrigues A, Tos P, Fornaro M, Boux E, et al. Low-power laser biostimulation enhances nerve repair after end-to-side neurorrhaphy: a double-blind randomized study in the rat median nerve model. Lasers Med Sci. 2004;19(1):57-65.

36. Rochkind S, Geuna S, Shainberg A. Chapter 25: Phototherapy in peripheral nerve injury: effects on muscle preservation and nerve regeneration. Int Rev Neurobiol. 2009;87:445-64.

37. Fernandes KCBG, Polacow MLO, Guirro RRJ, Campos GER, Somazz MC, Pinto VF, et al. Análise morfométrica dos tecidos muscular e conjuntivo após desnervação e estimulação elétrica de baixa frequência. Rev Bras Fisioter. 2005:9(2):235-41.

38. Reis FA, Belchior ACG, Nicolau RA, Fonseca TS, Carvalho PTC. Efeito da terapia com laser de arsenieto de gálio e alumínio $(660 \mathrm{Nm})$ sobre a recuperação do nervo ciático de ratos após lesão por neurotmese seguida de anastomose epineural: análise funcional. Rev Bras Fisioter. 2008;12(3):215-21.

39. Caierão QM, Betini J, Teodori RM, Minamoto VB. 0 efeito do intervalo da estimulação elétrica no músculo desnervado de rato. Rev Bras Fisioter. 2008;12(2):143-8.

40. Teodori RM, Silva AM, Silva MT, Oliveira LS, Polacow MLO, Guirro ECO. High-voltage electrical stimulation improves nerve regeneration after sciatic crush injury. Rev Bras Fisioter 2011;15(4):325-31 